\title{
Direct FuelCell/Turbine Power Plant
}

\author{
Annual Technical Progress Report \\ for
}

Period November 1, 2003 through October 31, 2004

Hossein Ghezel-Ayagh

Principal Investigator

November 19, 2004

DOE Grant No. DE-FC26-00NT40798

\author{
Prepared for: \\ U.S. Department of Energy \\ National Energy Technology Laboratory \\ P.O. Box 10940 \\ Pittsburgh, PA 15236-0940
}

Prepared by:

FuelCell Energy, Inc.

3 Great Pasture Road

Danbury, CT 06813 


\section{DISCLAIMER}

"This report was prepared as an account of work sponsored by an agency of the United States Government. Neither the United States Government nor any agency thereof, nor any of their employees, makes any warranty, express or implied, or assumes any legal liability or responsibility for the accuracy, completeness, or usefulness of any information, apparatus, product, or process disclosed, or represents that it's use would not infringe privately owned rights. Reference herein to any specific commercial product, process, or service by trade name, trademark, manufacturer, or otherwise does not necessarily constitute or imply its endorsement, recommendation, or favoring by the United States Government or any agency thereof. The views and opinions of authors expressed herein do not necessarily state or reflect those of the United States Government or any agency thereof." 


\section{ABSTRACT}

This report includes the progress in development of Direct FuelCell/Turbine ${ }^{\circledR}\left(\mathrm{DFC} / \mathrm{T}^{\circledR}\right)$ power plants for generation of clean power at very high efficiencies. The DFC/T power system is based on an indirectly heated gas turbine to supplement fuel cell generated power. The DFC/T power generation concept extends the high efficiency of the fuel cell by utilizing the fuel cell's byproduct heat in a Brayton cycle. Features of the DFC/T system include: electrical efficiencies of up to $75 \%$ on natural gas, $60 \%$ on coal gas, minimal emissions, simplicity in design, direct reforming internal to the fuel cell, reduced carbon dioxide release to the environment, and potential cost competitiveness with existing combined cycle power plants.

FCE successfully completed testing of the pre-alpha sub-MW DFC/T power plant. This power plant was constructed by integration of a $250 \mathrm{~kW}$ fuel cell stack and a microturbine. Following these proof-of-concept tests, a stand-alone test of the microturbine verified the turbine power output expectations at an elevated (representative of the packaged unit condition) turbine inlet temperature. Preliminary design of the packaged sub-MW alpha DFC/T unit has been completed and procurement activity has been initiated. The preliminary design of a $40 \mathrm{MW}$ power plant including the key equipment layout and the site plan was completed. A preliminary cost estimate for the $40 \mathrm{MW}$ DFC/T plant has also been prepared. The tests of the cascaded fuel cell concept for achieving high fuel utilizations were completed. The tests demonstrated that the concept results in higher power plant efficiency. Alternate stack flow geometries for increased power output/fuel utilization capabilities are also being evaluated. 
Contract No. DE-FC26-00NT40798

Annual Technical Progress Report
Direct FuelCell/Turbine Power Plant November 1, 2003 through October 31, 2004

\section{Table of Contents}

1.0 Executive Summary

Page No.

1

2.0 Experimental 2

2.1 SubMW DFC/T Proof-of-Concept Tests 2

2.2 High Efficiency-High Power Output Fuel Cell Development 3

3.0 Results and Discussions 4

3.1 Stand-alone Microturbine Tests 4

3.2 SubMW Packaged DFC/T Power Plant Design 6

$\begin{array}{lll}\text { 3.3 } & \text { Multi-MW Power Plant Design } & 7\end{array}$

3.4 High Efficiency - High Power Output Fuel Cell Design 12

$\begin{array}{lll}4.0 & \text { Conclusion } & 14\end{array}$

$\begin{array}{lll}5.0 & \text { References } & 17\end{array}$ 


\subsection{EXECUTIVE SUMMARY}

FCE successfully completed testing of the pre-alpha sub-MW DFC/T power plant. This first-of-a-kind grid-connected power plant facility was constructed by integration of a $250 \mathrm{~kW}$ DFC stack and a $60 \mathrm{~kW}$ Capstone microturbine. The main objective of the tests was the development of the technologies to lead to design of highly efficient and environmentally green power generation units using the existing natural gas infrastructure. Tests were conducted to develop the procedures for startup, normal operation, and shutdown of the hybrid power plant. The technology developed as a result of these proof-of-concept demonstration tests is being used to optimize the design of subMW- class packaged DFC/T power generation units. Stand-alone tests of the microturbine were conducted to characterize turbine performance at turbine inlet temperature (TIT) higher than that achieved in the integrated tests above, and representative of that expected in the packaged unit. Capstone's expected performance at $1400^{\circ} \mathrm{F}$ TIT was verified in the stand-alone tests.

The preliminary design of the subMW DFC/T packaged unit (DFC300/T) was completed. Design modifications to the existing DFC300A fuel cell module for its application to the DFC300/T unit were completed. The safety review of the DFC300/T system design, using the widely implemented Hazard and Operability (Hazop) discipline, was conducted. The set of piping and instrumentation diagrams (P\&IDs) was refined. Specifications for major equipment were prepared for vendor quotations, based on mass and energy balances. Suppliers for key equipment were selected. Threedimensional equipment and piping layouts were completed. All major equipment and instrumentation items were ordered. The procurement activities continue.

A preliminary $40 \mathrm{MW}$ DFC/T power plant plot plan, including key balance-of-plant (BOP) equipment and fuel cell module layouts, was prepared. The $40 \mathrm{MW}$ hybrid power plant has been designed with $30 \mathrm{MW}$-class (M-10, nominal one-MW fuel cell package) modules and a modified commercial gas turbine. A major equipment list and specifications were prepared for vendor quotations, based on system mass and energy balances. Three-dimensional (3-D) configuration models were developed from vendorsupplied information for the key BOP equipment in the power plant. The design of the piping system, including the pipe sizes, insulation requirements and pipe routing, was completed. The procedures for start-up/heat-up of the hybrid power plant were developed. The start-up strategy utilizes firing of the gas turbine and auxiliary duct burners with supplementary natural gas for heat-up of the fuel cell modules and the BOP equipment. The process controls were defined and a detailed process flow diagram (PFD) was developed. The electrical one-line diagrams for power production and plant auxiliary power were prepared. A preliminary cost estimate for the $40 \mathrm{MW}$ plant was also prepared.

A study of the 'cascaded anode' fuel cell configuration was conducted for high efficiency, high power output fuel cell development. System analysis using computer modeling was performed. Tests were designed and conducted using a $20 \mathrm{~kW}$ DFC stack. The capability for increasing fuel utilization was assessed. A $10 \%$ gain in fuel 
utilization, which corresponds to an increase in efficiency of 5 percentage points, is achievable. In addition, alternate stack flow geometry concepts including counter flow design are being evaluated using a computational flow dynamics (CFD) modeling tool. This component modification approach is intended for increased stack power output/fuel utilization capabilities.

\subsection{EXPERIMENTAL}

\subsection{SubMW DFC/T Proof-of-Concept Tests}

The proof-of-concept test of the fuel cell/gas turbine hybrid system in the sub-MW power plant facility at Danbury, CT was continued. The test included operation of a 250 kW full-size stack integrated with a Capstone C60 microturbine in a grid-connect mode (Figure 1). Thermal management of the system was confirmed by increasing microturbine expander inlet temperature while controlling fuel cell operating temperature. The control strategies were refined based on the operational experience. The system trip/emergency shutdown scenarios were tested successfully. The power plant operation was demonstrated using the microturbine as the only source of fresh air supply to the system. $\mathrm{NO}_{x}$ emission levels of less than $0.25 \mathrm{ppm}$ were achieved. The proof-of-concept test was completed achieving the milestone for operation of the world's first grid-connected power plant.

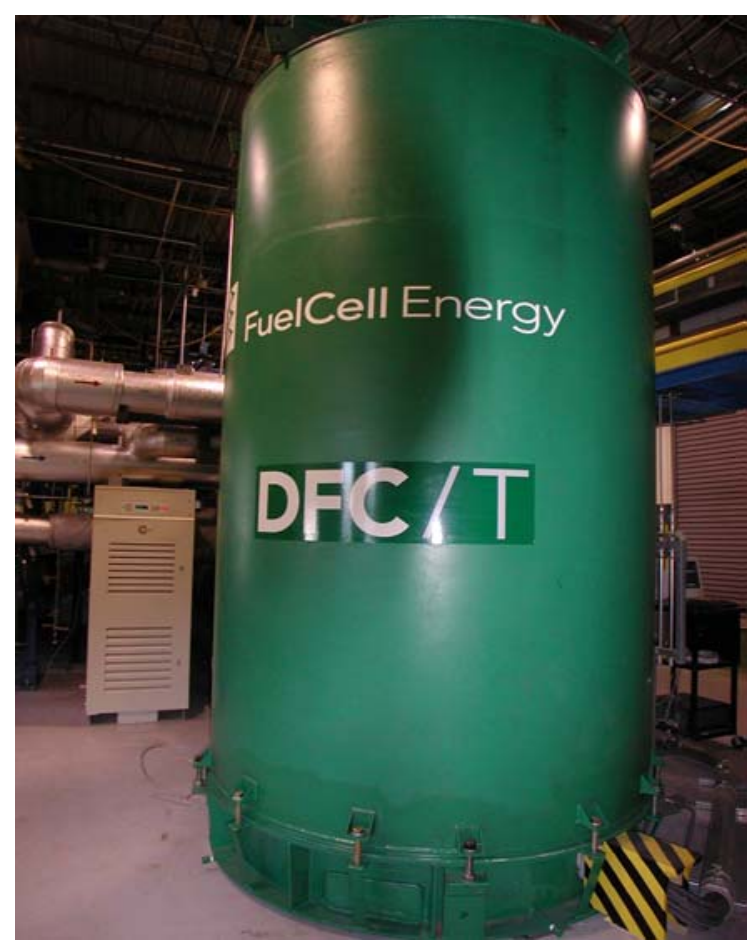

Figure 1. SubMW DFC/T HYBRID POWER PLANT FACILITY:

Full-Size DFC Stack Was Integrated With Capstone C60 Microturbine

After the completion of the above test, the microturbine was de-integrated from the fuel cell facility for stand-alone testing. Microturbine power output was characterized at 
higher TIT for verification of Capstone performance projections. A photograph of the stand-lone test setup is included in Figure 2. As shown, a catalytic oxidizer was incorporated in the assembly and hydrogen was provided as fuel to achieve the desired TIT. The piping system from the compressor outlet to the turbine inlet included an expansion joint and was designed to reduce side loading of the microturbine nozzles/casing. The microturbine power output was characterized as a function of turbine back pressure (varied up to $\sim 35 \mathrm{inWC}$ ) at a baseline TIT of $1250^{\circ} \mathrm{F}$ and at a higher TIT of $1400^{\circ} \mathrm{F}$. The test results are reported in Subsection 3.1.

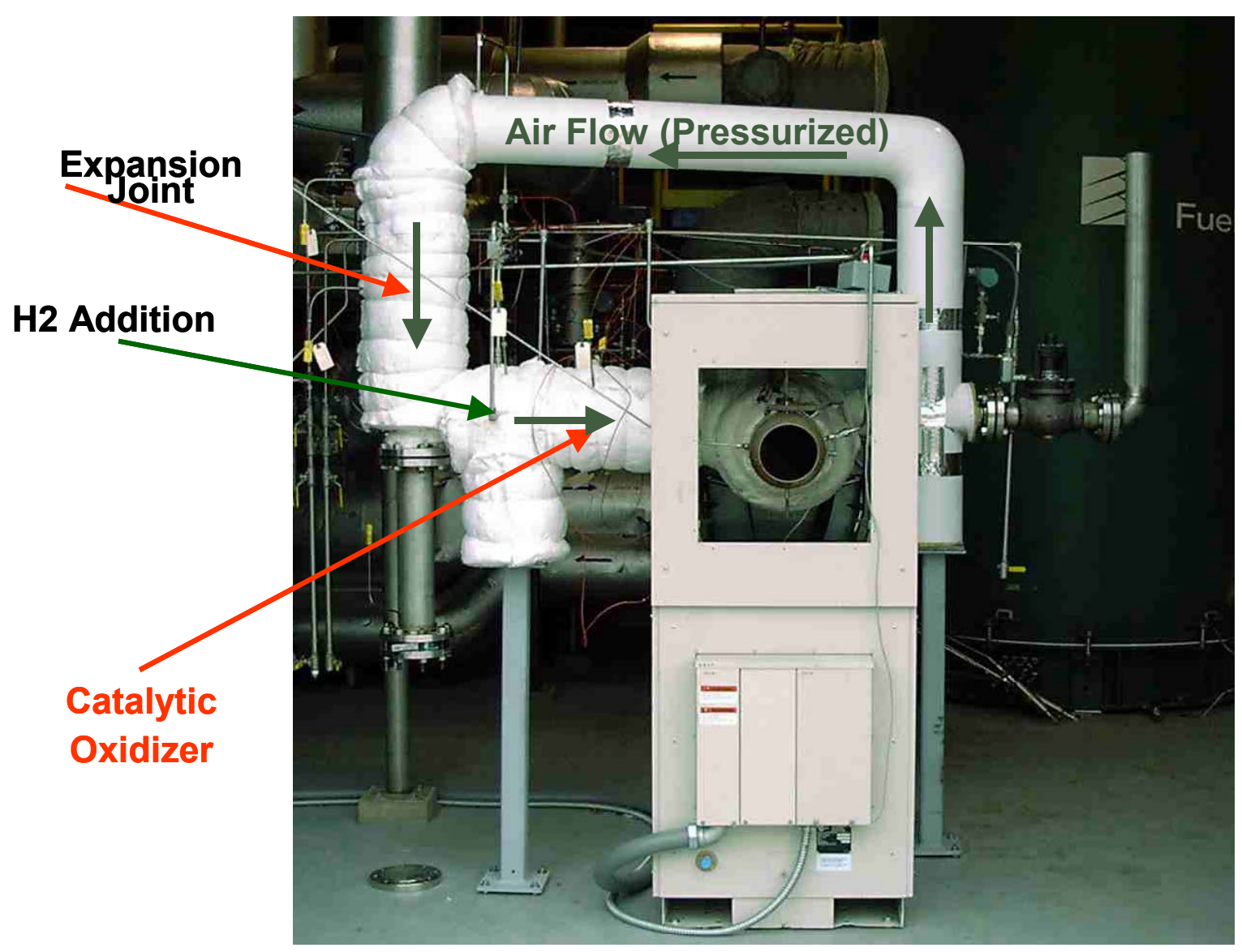

Figure 2. STAND-ALONE MICROTURBINE (C60) TEST SET-UP:

Piping System Was Designed To Reduce Side-Loading Of C60 Nozzles/Casing

\subsection{High Efficiency-High Power Output Fuel Cell Development}

In the DFC/T hybrid power cycle, the fuel cell produces more than eighty percent of the power with the remainder being generated by the gas turbine. Operation of the fuel cell at high fuel utilization will result in increased power plant net efficiency. One approach being considered to increase fuel utilization by $5 \%$ or more is a system modification involving cascaded fuel cells. In this configuration, two fuel cell stacks are arranged in series with respect to the fuel stream (Figure 3). The downstream stack receives 


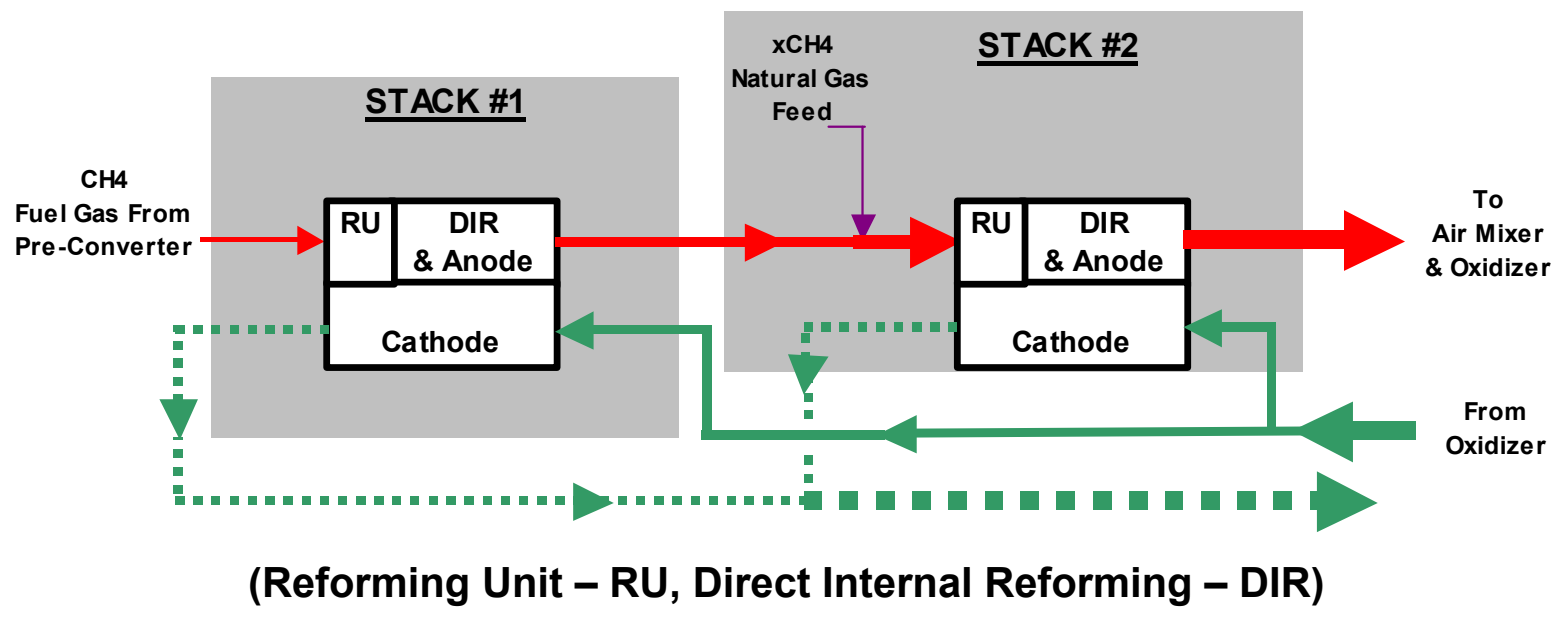

Figure 3. CASCADED ANODE SYSTEM (CAS) CONCEPT:

Fuel Cell Stacks Are Arranged In Series With Respect To Fuel Stream

unused fuel exiting from the upstream stack, in addition to the fresh fuel. A system analysis of the cascaded anode concept was performed using a CHEMCAD process simulation model. Experiments were designed for a $20 \mathrm{~kW}$ fuel cell stack. Fuel feed compositions and flow rates for the two stacks in a cascading anode configuration were computed. A $20 \mathrm{~kW}$ DFC stack was tested simulating the two feed gases (Figure 4). The stack performance and thermal characteristics were recorded. Testing included simulating the downstream stack in a cascading configuration while keeping the current density constant to vary the fuel utilization. The test results are summarized and discussed in Subsection 3.4.

\subsection{RESULTS AND DISCUSSIONS}

\subsection{Stand-alone Microturbine Tests}

As reported in Subsection 2.1, stand-alone microturbine tests were conducted to verify Capstone performance projections at higher TIT. Microturbine power output was characterized as a function of turbine backpressure. Figures 5 and 6 show the characterizations at $\mathrm{TIT}$ of $1250^{\circ} \mathrm{F}$ and $1400^{\circ} \mathrm{F}$, respectively. TIT of $1250^{\circ} \mathrm{F}$ represents the temperature that was observed in fuel cell integrated tests in the sub-MW power plant facility. Whereas, TIT of $1400^{\circ} \mathrm{F}$ represents the higher TIT expected in the packaged sub-MW DFC/T demonstration unit because of reduced heat losses. Capstone's expectations of turbine performance are also included in the plots for comparison. A turbine power output of $\sim 27 \mathrm{~kW}$ was observed at $1400^{\circ} \mathrm{F}$ TIT and 20 inWC backpressure with $90 \mathrm{krpm}$ turbine speed. The turbine power output observed during the stand-alone tests matched the expected theoretical values based on Capstone's cycle analysis. 


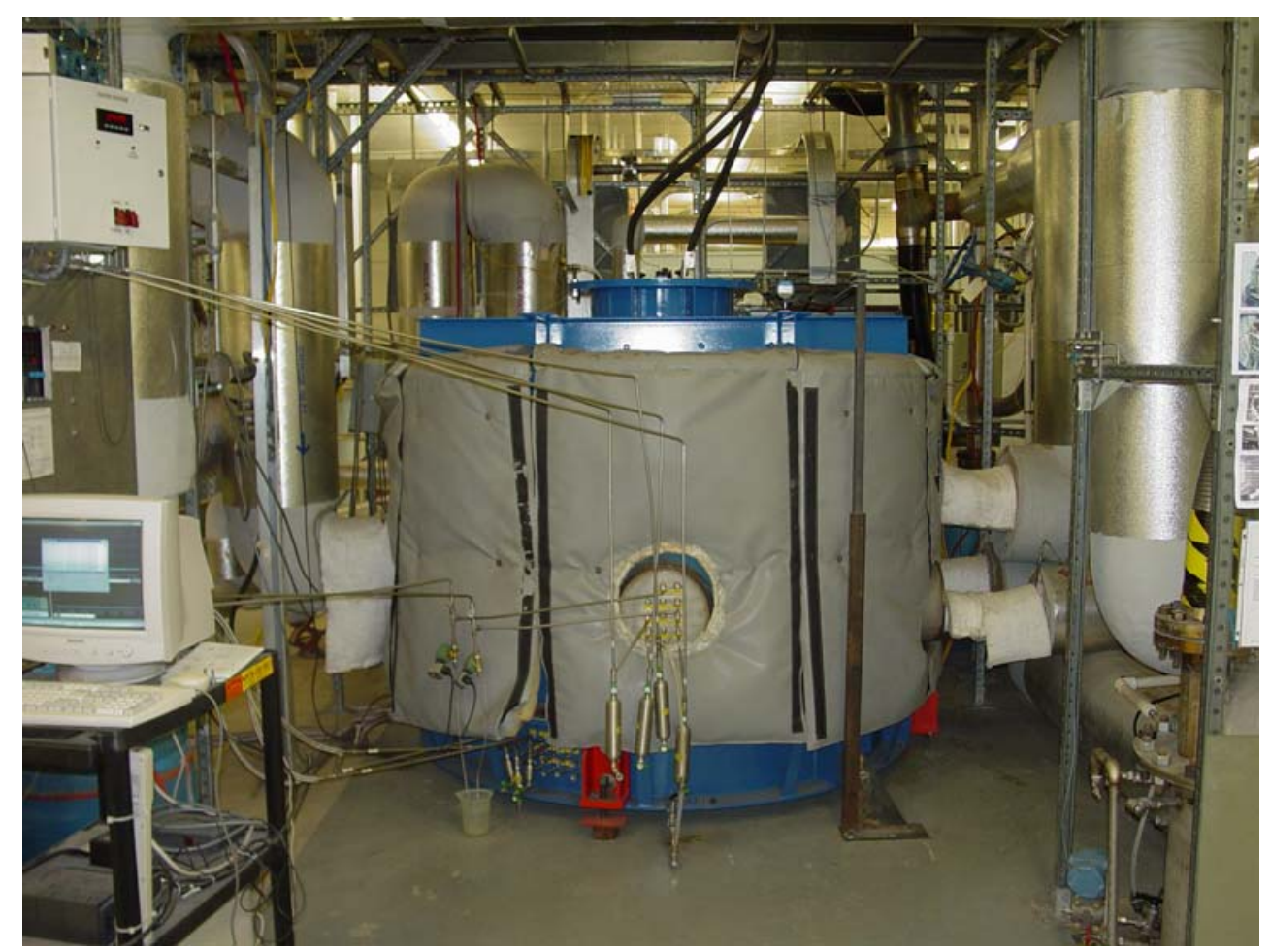

Figure 4. 20 kW STACK USED FOR TESTS OF CASCADED FUEL CELL CONCEPT:

Simulated Fuel Feed Was Used When Testing As Downstream Stack

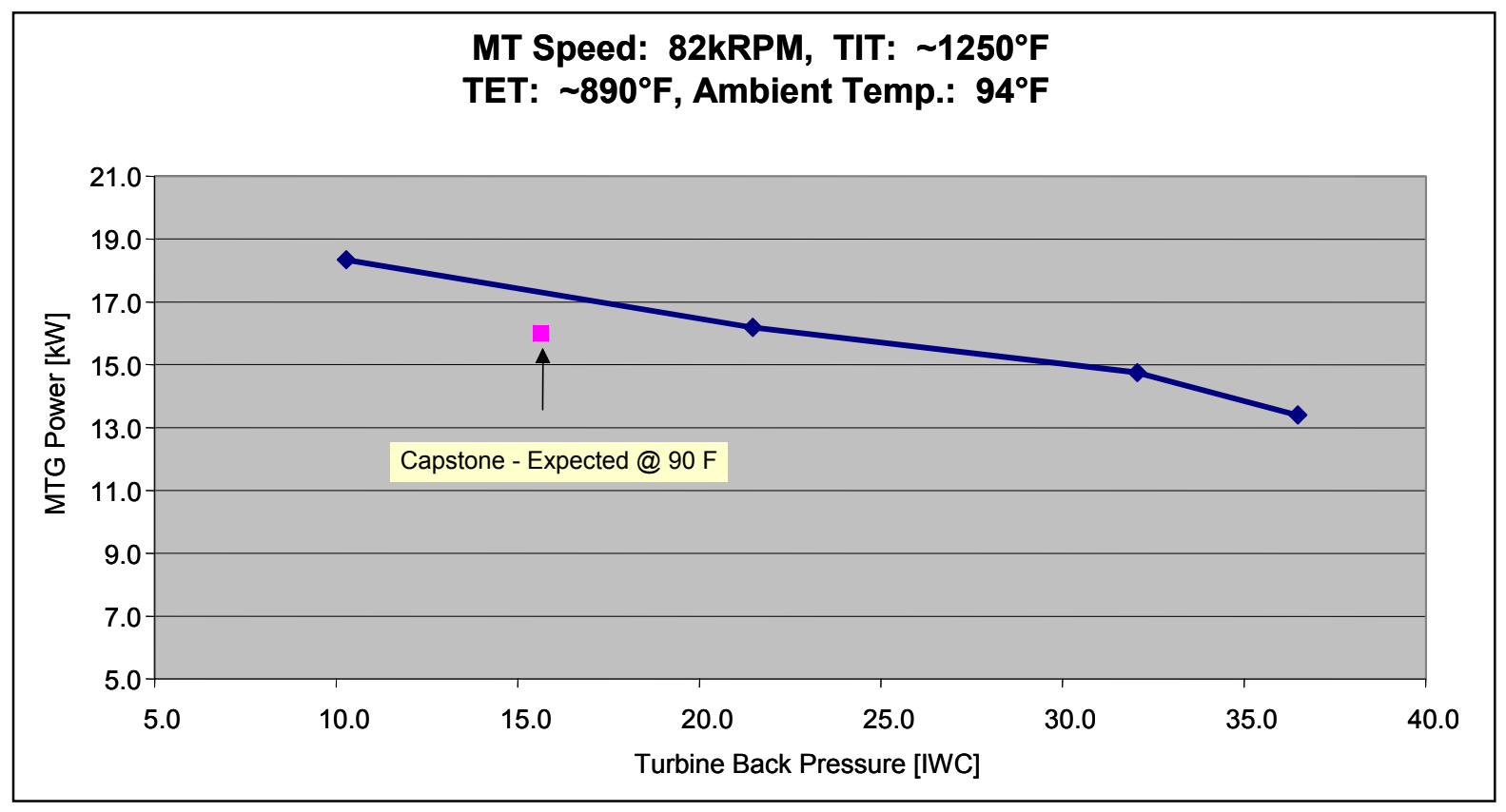

Figure 5. MICROTURBINE (C60) PERFORMANCE CHARACTERIZATION AT $1250^{\circ} \mathrm{F}$ TIT:

The Turbine Performance In Stand-Alone Test Matched The Expected Power 


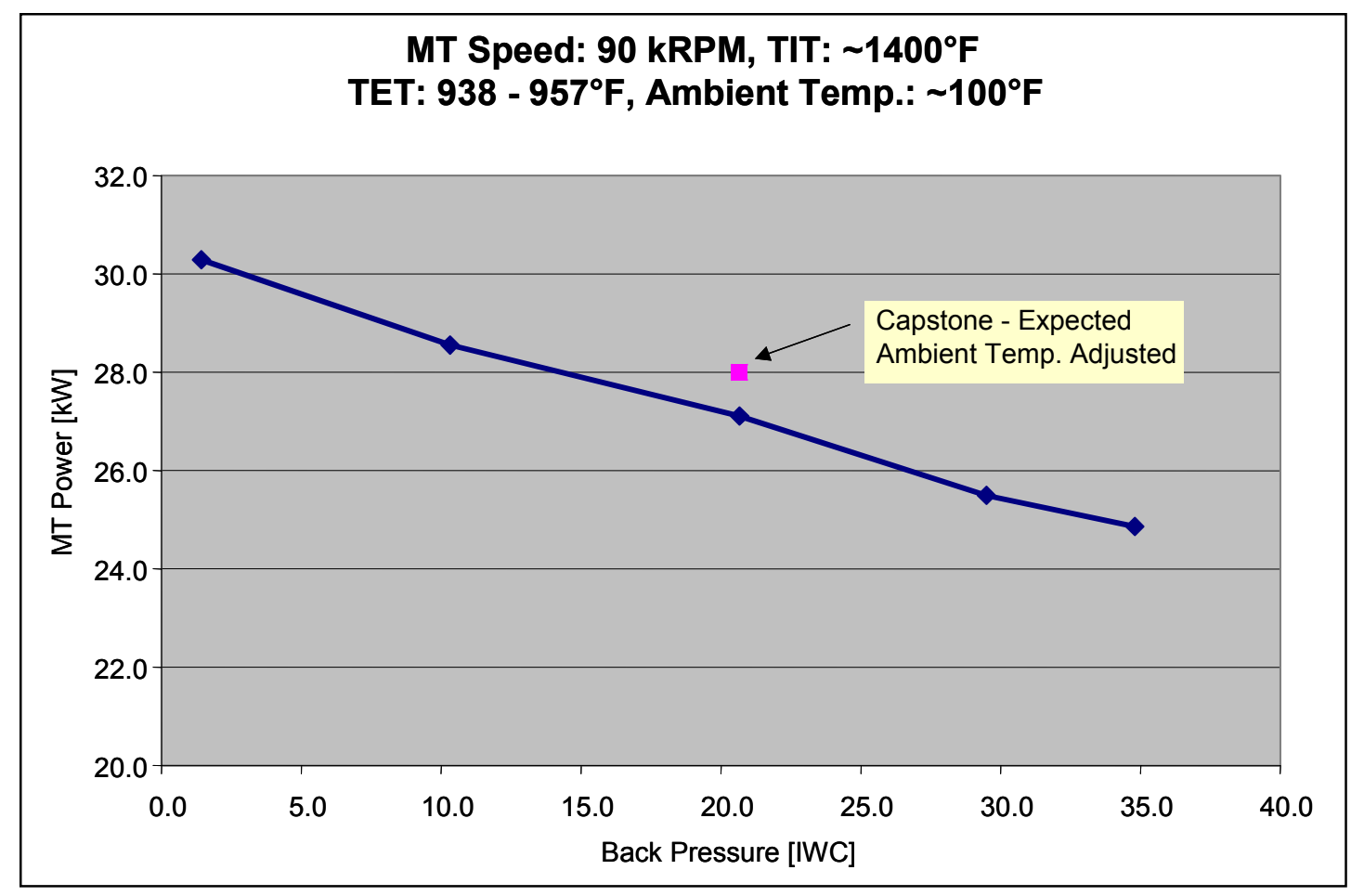

Figure 6: MICROTURBINE (C60) PERFORMANCE CHARACTERIZATION AT $1400^{\circ} \mathrm{F}$ TIT:

The Turbine Power Output Of 25-30 kW Is Expected With Increased TIT

\subsection{SubMW Packaged Power Plant Design}

The preliminary design of the subMW packaged alpha demonstration unit was completed. The design included packaging the fuel cell and the microturbine in a single truck-transportable module (DFC300/T). The design activities accomplished are listed below.

- The design modifications of existing DFC300A fuel cell module for application to the DFC300/T system were completed. Major modifications included anode-exhaust pipe spool redesign to direct the stream to balance-of-plant, and the cathode-in flow distributor for thermal uniformity of cathode-in gas to the stack.

- A safety review of the DFC300/T system was conducted based on the Hazop methodology utilized widely by the process industries.

- Mass and energy balances for rated operation and design conditions, and for power plant start-up conditions were completed. A process flow diagram was generated including the major operating equipment along with the plant start-up equipment. 
- The set of Piping and Instrumentation Diagrams (P\&IDs) was completed incorporating design information and recommendations from subMW proof-ofconcept test results, DFC300 product data and the Hazop Safety Review mentioned above. This includes P\&IDs for the process, utilities and mechanical designs.

- The process equipment specifications were prepared. The design alternatives and vendors for the key equipment were evaluated. Equipment suppliers for equipment such as microturbine, recuperators, and anode gas oxidizer were selected.

- Three-dimensional equipment (process, utility and other) and piping layout drawings were prepared using the Intergraph plant design software. Provisions for lifting and transportation were incorporated. Figures 7 and 8 show the isometric views of the DFC300/T sub-MW packaged unit layout.

- Pipe stress analysis was completed generating specifications for expansion joints and pipe supports. The equipment structural steel support design was also completed.

- Preliminary mechanical design, including ventilation fans, compartment heaters, and other HVAC related components, was completed. The enclosure design included access doors, compartment barriers, roof access panels, and enclosure wall penetrations.

- Specifications for all valves including safety valves, and pressure regulators were prepared and bids were solicited from the suppliers.

- Design parameters and specifications were developed for key instrument and control equipment.

All major equipment and instrumentation items have been ordered. Some of the equipment and parts have been received. The procurement activity will continue into the next reporting period.

\subsection{Multi-MW Power Plant Design}

The baseline DFC/T configuration included a high temperature recuperator. The multiMW power plant performance (power output and efficiency) estimations for the near, intermediate and long-term systems, based on this configuration, were reported in the previous annual report. The system simulation runs (performed using CHEMCAD) were refined and the updated performance estimates are presented in Table 1. For comparison, performance estimations for the DFC-only systems are also shown in Table 1. The integration of the fuel cell with turbine in a hybrid system offers significant improvement in power plant electrical efficiency. The mid-term and long-term estimates are both based on improved fuel cell performance. The long-term system, in addition, employs an advanced gas turbine (intercooled and reheat cycle) and has a potential to offer system electrical efficiency approaching $75 \%$ (LHV natural gas). 


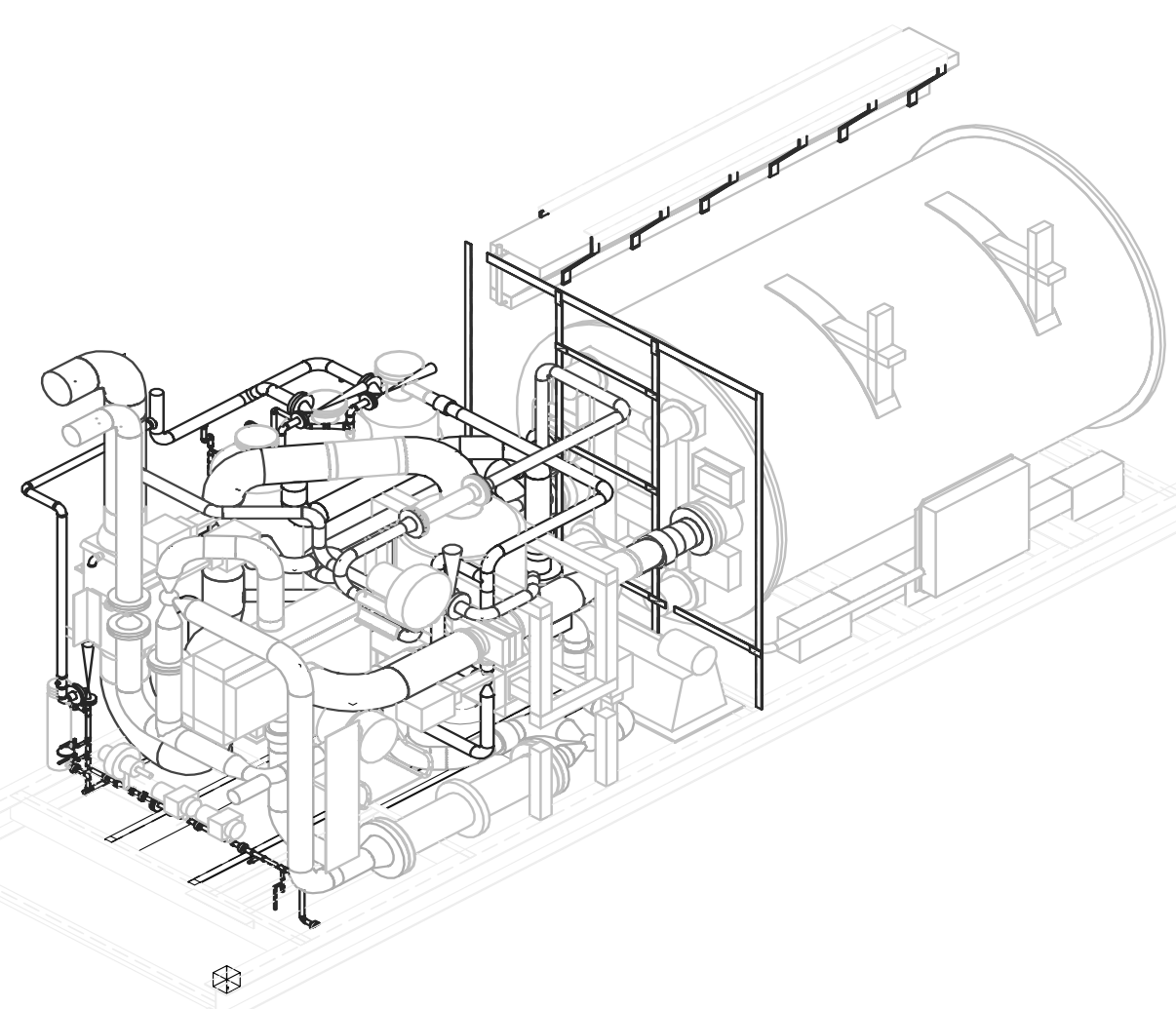

Figure 7. DFC300/T SUB-MW PACKAGED UNIT LAYOUT: Isometric View Showing One Side

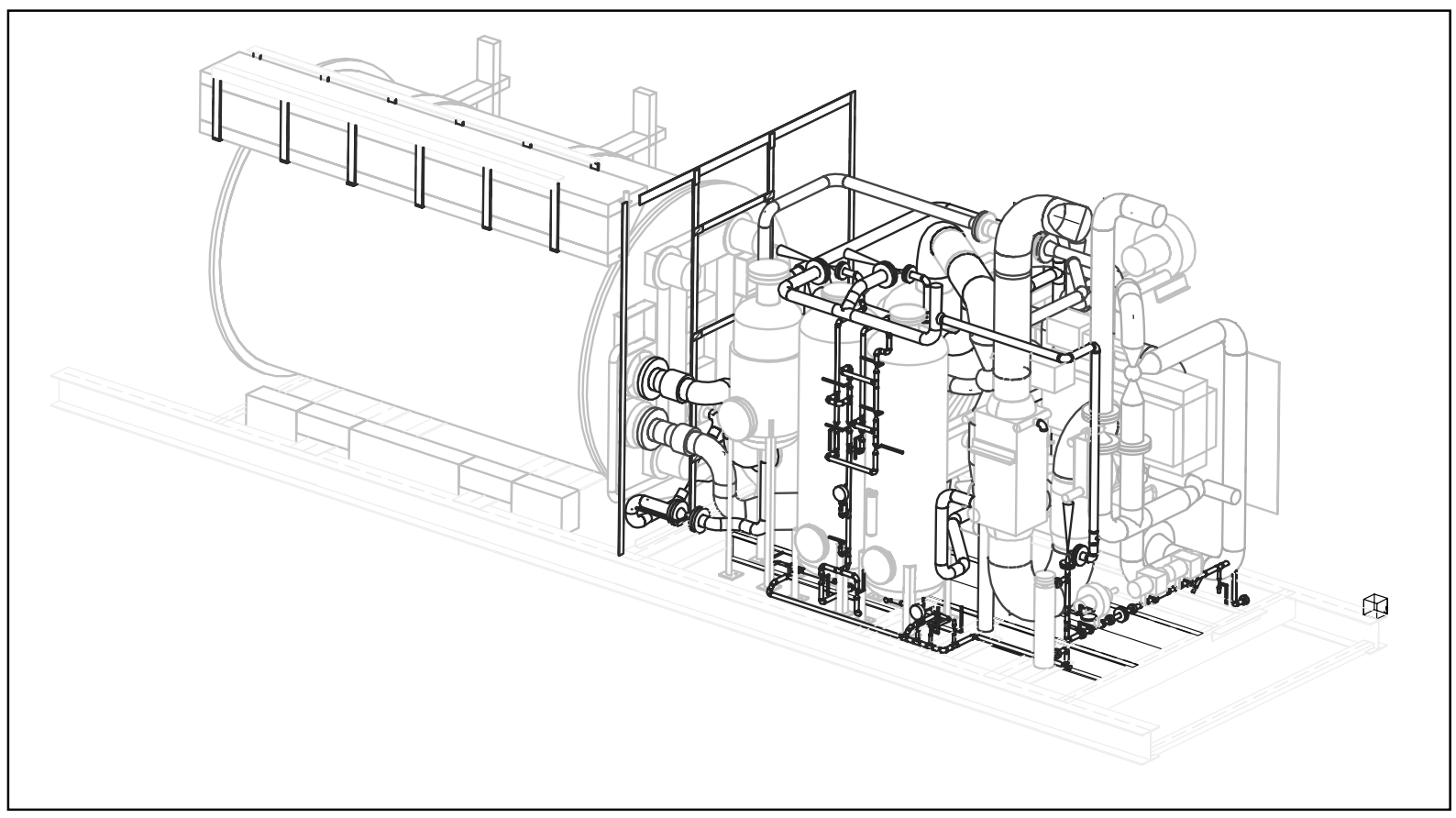

Figure 8. DFC300/T SUB-MW PACKAGED UNIT LAYOUT: Reverse Isometric View 


\section{Table 1. MULTI-MW DFC/T POWER PLANT (BASELINE CONFIGURATION) PERFORMANCE PROJECTIONS:}

Hybrid System Has Potentially Significant Efficiency Gain Over DFC-only System

\begin{tabular}{|c|c|c|c|c|c|}
\hline & Near. & & Mid-1 & Term & Long-Term \\
\hline & DFC & $\begin{array}{l}\text { DFC/T } \\
\text { Hybrid }\end{array}$ & $\begin{array}{l}\text { Improved } \\
\text { DFC }\end{array}$ & \begin{tabular}{|c|} 
DFC/T Hybrid \\
With Improved \\
DFC
\end{tabular} & \begin{tabular}{|c|} 
DFC/T Hybrid \\
With Intercooled \\
\& Re-heat \\
Gas Turbine \\
\end{tabular} \\
\hline Fuel Cell: & & & & & \\
\hline DC Power Out, MW & 12.0 & 12.0 & 16.8 & 16.8 & 33.5 \\
\hline AC Power Out, Gross, MW & 11.3 & 11.3 & 16.4 & 16.3 & 32.7 \\
\hline Gas Turbine: & & & & & \\
\hline Expander Power, MW & & $\begin{array}{r}7.9 \\
(5.3)\end{array}$ & & $\begin{array}{r}8.7 \\
(5.9\end{array}$ & $\begin{array}{r}20.7 \\
(10.9)\end{array}$ \\
\hline $\begin{array}{l}\text { Compressor Power, MW } \\
\text { Net AC Out, MW }\end{array}$ & & $\begin{array}{r}(0.3) \\
2.5\end{array}$ & & 2.6 & 9.3 \\
\hline Air Blower Power, MW & (0.3) & & (0.3) & & \\
\hline Auxiliary Power Consumption, MW & (0.1) & (0.1) & (0.1) & (0.1) & (0.2) \\
\hline Net Power Output, MW & 11.0 & 13.7 & 15.9 & 18.8 & 41.8 \\
\hline Efficiency, \% LHV Natural Gas & $49.9 \%$ & $62.0 \%$ & $57.0 \%$ & $67.0 \%$ & $74.6 \%$ \\
\hline
\end{tabular}

The preliminary design of a $40 \mathrm{MW}$ power plant for near-term application was completed. The design is based on a scalable approach using FCE's existing MW-class fuel cell modules (M-10) in a cluster arrangement. The fuel cell cluster design, shown in Figure 9, has five M-10 modules in a cluster with distribution piping for the fuel and oxidant gases. Expansion joints have been incorporated for the cluster piping.

Based on the scalable overall plant design concept, the plant is arranged in three sections in addition to the centralized equipment. Each section consists of two clusters of five M-10 fuel cell modules together with supporting equipment. The supporting equipment includes: fuel preconverter, air blower, heat exchangers and two power conditioning units. The centralized equipment, which supports all three sections, includes a gas turbine, an anode gas compressor, an anode gas oxidizer and other site equipment such as a fuel clean-up system and a water treatment system.

The performance of the $40 \mathrm{MW}$ power plant, estimated based on near-term fuel cell performance and commercially available gas turbines, is presented in Table 2 . The key characteristics of the gas turbine for the $40 \mathrm{MW} D F C / T$ system include: $76 \mathrm{lb} / \mathrm{s}$ airflow, 7.8 pressure ratio and $1800^{\circ} \mathrm{F}$ TIT. The gas turbine selected for the $40 \mathrm{MW}$ plant design is a Man Turbo Model 1304-11. MAN TURBO's THM heavy-duty industrial gas turbine (shown in Figure 10) is widely used as a driver for compressors, pumps or electric generators. The THM gas turbine features rugged industrial design, and two externally located combustion chambers that can be modified to direct the compressor air to the system recuperator and the heated air back to the turbine. 


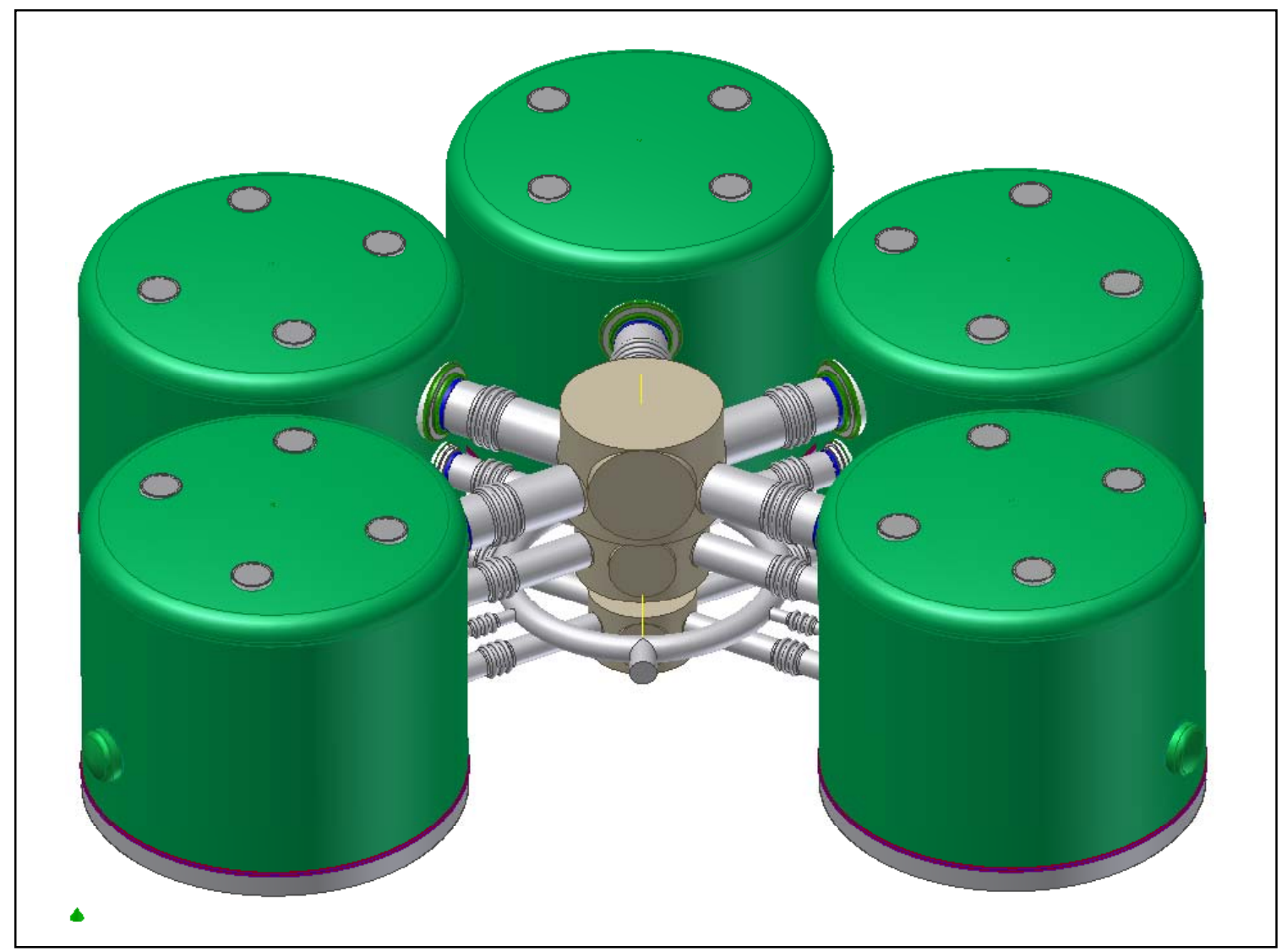

Figure 9. M-10 FUEL CELL MODULE CLUSTER DESIGN:

MW-class Modules In Cluster Are Connected By Radial Gas Distribution Piping

Table 2. MULTI-MW DFC/T HYBRID PLANT PERFORMANCE:

Fuel Cell Is Primary Source Of Power Providing Over $80 \%$ Of Total Power Output

\begin{tabular}{|l|c|}
\hline \multicolumn{1}{|c|}{ Plant Size } & 40 MW \\
\hline Fuel Cell & \\
DC Power Output, MW & 36.1 \\
AC Power Output, MW & 34.3 \\
\hline Gas Turbine & \\
Expander Power, MW & 21.8 \\
Compressor Power, MW & $(10.4)$ \\
Net AC Power, MW & 10.8 \\
\hline Plant Parasitic Load & \\
Anode Gas Compressor, MW & $(3.6)$ \\
Other Auxiliary Loads, MW & $(0.8)$ \\
\hline Net Power Output, MW & 40.8 \\
\hline Efficiency, \% (LHV of Natural Gas) & 61.8 \\
\hline
\end{tabular}




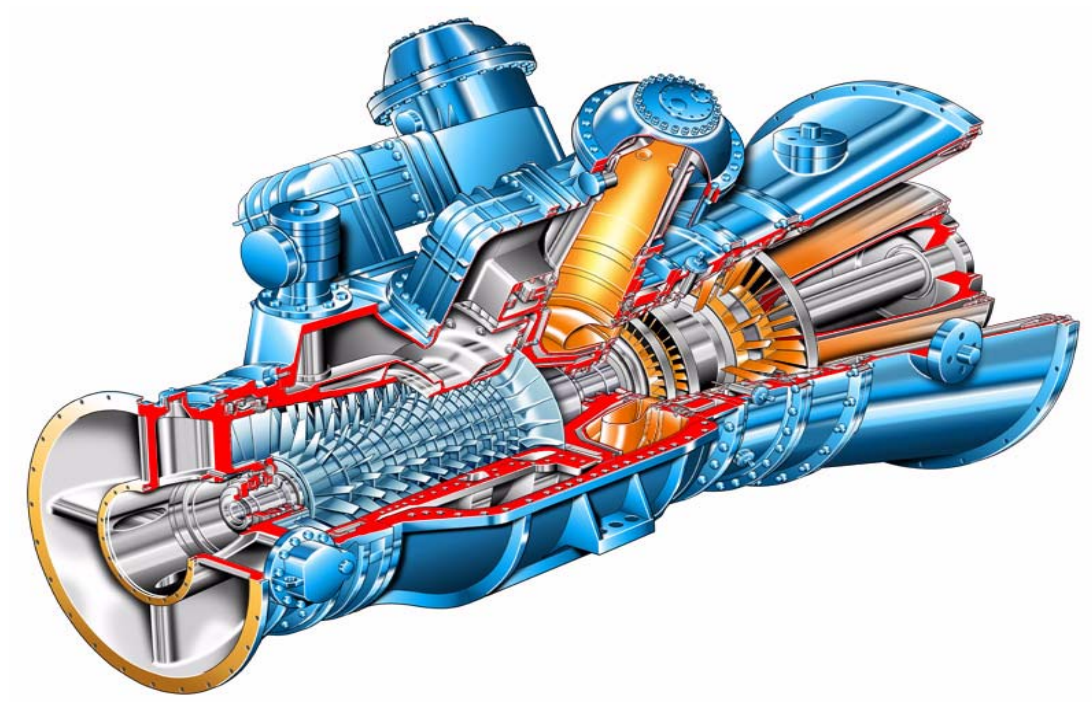

Figure 10. MAN 1304-11 GAS TURBINE:

This Commercially Available Turbine Is Rugged In Construction

The process flow diagram with process controls for normal operation and start-up heating was generated. Auxiliary duct burners are incorporated upstream of the cathode inlet for power plant startup. The gas turbine/oxidizer and auxiliary duct burners are fired with supplementary natural gas to heat up the fuel cell modules and BOP equipment. On the anode side, small electric start-up heaters are provided to preheat fuel stream to prereformer inlet and fuel cell inlet temperatures. Electrical oneline diagrams were prepared for the power generation and auxiliary power needs. Equipment specifications were prepared for key pieces of equipment and subsystems. Potential suppliers were contacted and preliminary configuration information and cost estimates were obtained.

The fuel clean-up subsystem is a centralized desulfurizer for the natural gas fuel using activated carbon in an epoxy lined carbon steel vessel. Prereforming of the fuel for each of the three plant sections is performed in a preconverter containing nickel based catalyst (in a stainless steel vessel).

The power conditioning system (PCS) converts the \pm 300 VDC from the fuel cells to 13.8 $\mathrm{kV}$ and is modular. A PCS module supports each fuel cell cluster. The $6000 \mathrm{~kW}$ modular unit includes IGBT based inverters. The assembly is in a NEMA 3R outdoor rainproof enclosure. The system also includes a step-up transformer. Efficiency of the PCS is $>94 \%$. In all operating modes the system is designed to draw equal current from each of the five fuel cell modules (in the cluster).

The central control system (CCS) for the $40 \mathrm{MW}$ plant is designed to coordinate the output of the three plant sections including the output from the six PCS systems. It provides operational sequence control for plant start-up heating, on-load operation, and normal and emergency shutdowns. The centralized system is housed in an outdoor rainproof enclosure. 
An overall layout of the $40 \mathrm{MW}$ plant is shown in Figure 11. The site is approximately $273^{\prime} \times 325^{\prime}$ in size. The arrangement of equipment on the site evolved from the considerations of providing easy access to the equipment for maintenance and replacement, and to minimize the distance for the largest process piping. Design of the site arrangement included sizing of all the process piping and the development of process pressure profiles consistent with performance estimates. Thermal insulation requirements were established for all the process piping based on surface touch temperature limit criteria. A computer model was developed for detailed design of the piping system including pipe sizes and insulation thickness requirements.

The capital cost for the $40 \mathrm{MW}$ plant was developed based on equipment supplier preliminary quotations, and process plant cost estimating standards. The M-10 fuel cell module cost was based on FCE's business plan and projections of cost at increasing production levels by FCE's Torrington, CT manufacturing facility. Cost improvements based on a reasonable learning curve were incorporated in the projections. With future fuel cell technology developments enabling higher power operations of fuel cell modules, further cost reductions are expected.

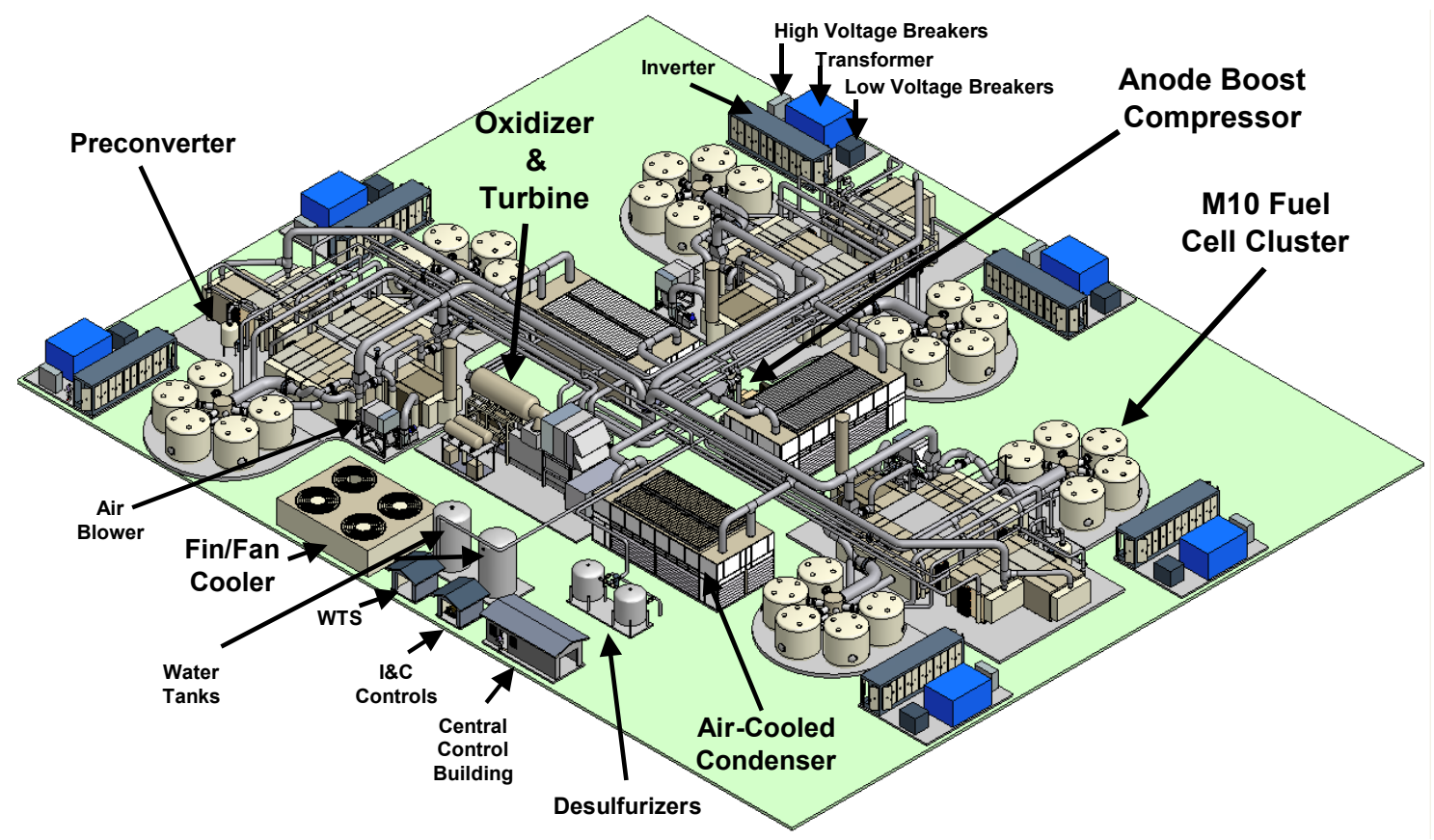

Figure 11. 40 MW DFC/T POWER PLANT LAYOUT:

Plant Is Divided Into Three Sections, Each Containing A Pair Of Fuel Cell Clusters

\subsection{High Efficiency-High Power Output Fuel Cell Design}

Tests conducted on a $20 \mathrm{~kW}$ DFC stack to characterize the stack performance and thermal profiles for the 'cascading anode' stacks, were discussed under Subsection 2.2. Table 3 lists the key performance characteristics related to operational and thermal profile parameters for the series of tests conducted. The stack thermal profiles 
Table 3. KEY STACK PERFORMANCE PARAMETERS AND THERMAL PROFILES
OBSERVED DURING CASCADED ANODE CONCEPT TEST:

A 10\% Gain In Fuel Utilization Is Possible

\begin{tabular}{|c|c|c|c|c|c|}
\hline \multicolumn{2}{|c|}{$\begin{array}{l}\text { Test } \\
\text { Stack \# (in cascaded anode configuration) } \\
\text { Description }\end{array}$} & $\begin{array}{c}1 \\
1 \\
\text { Basis }\end{array}$ & $\begin{array}{c}2 \\
2 \\
1 \mathrm{XCH} 4\end{array}$ & $\begin{array}{c}3 \\
2 \\
0.75 \times \mathrm{CH} 4\end{array}$ & $\begin{array}{c}\mathbf{4} \\
1 \\
\text { Repeat }\end{array}$ \\
\hline $\begin{array}{l}\text { Current Density } \\
\text { Maximum Cell Temp. } \\
\text { Average Cell Temp. } \\
\text { Anode Chamber Pressure Drop } \\
\text { Stack Voltage } \\
\text { DC Power Output } \\
\text { Stack Fuel Utilization } \\
\text { Overall Fuel Utilization } \\
\text { UCO2 } \\
\text { UO2 }\end{array}$ & $\begin{array}{c}\text { mA/cm }{ }^{2} \\
\text { Deg. C } \\
\text { Deg. C } \\
\text { InWC } \\
\text { Volts } \\
\text { KW } \\
\% \\
\% \\
\% \\
\%\end{array}$ & $\begin{array}{c}139.8 \\
695 \\
643 \\
1.7 \\
22.8 \\
24.9 \\
72.6 \\
72.6 \\
71.3 \\
40.9\end{array}$ & $\begin{array}{c}138.0 \\
681 \\
616 \\
3.12 \\
22.1 \\
23.8 \\
57.9 \\
73.5 \\
60.4 \\
34.2\end{array}$ & $\begin{array}{c}138.3 \\
703 \\
660 \\
3.01 \\
22.1 \\
23.9 \\
69.0 \\
81.7 \\
69.4 \\
34.8\end{array}$ & $\begin{array}{l}139.9 \\
706 \\
656 \\
2.17 \\
22.6 \\
24.8 \\
73.0 \\
73.0 \\
70.8 \\
41.2\end{array}$ \\
\hline \multicolumn{6}{|l|}{ Stack Temperature Profile } \\
\hline
\end{tabular}


observed are also shown for comparison. Test 1 was a baseline test, simulating the upstream stack (Stack \#1) in a 'cascaded anode' configuration, at $\sim 140 \mathrm{~mA} / \mathrm{cm}^{2}$ and $\sim 73 \%$ fuel utilization. Test 2 column shows the results when simulating the downstream stack (Stack \#2) fed with the same amount of fresh fuel as Stack \#1, in addition to the anode exhaust stream (unused fuel) from Stack \#1. The overall fuel utilization (based on fresh fuel) for the two stacks is the same. But Stack \#2 is actually operating at lower utilization because it is also receiving unused fuel from Stack \#1. Because of high anode flow, Stack \#2 (Test \#2) is operating cooler (lower maximum and average cell temperatures) than Stack \#1 (Test \#1). Stack \#2 fuel utilization was increased in Test \#3 by decreasing the fresh fuel flow by $25 \%$. It can be seen that the fuel utilization for the stack increased from 58 to $69 \%$ and the overall utilization (based on fresh fuel) increased from $\sim 74$ to $82 \%$. The thermal profile of Stack \#2 (Test \#3) is similar to that of Stack \#1 (Test \#1). The power output for Stacks \#1 and \#2 were comparable. Overall, the results showed that a $\sim 10 \%$ gain in fuel utilization is possible. The net result of a $10 \%$ gain in fuel utilization translates into an increase of approximately 5 percentage points in overall efficiency of the system.

The above approach to high utilization/high power output stack design implies system modifications. Another approach is component modification, which involves reconfiguration of stack geometry and associated flow fields. Stack design studies for increased power output/fuel utilization capabilities have been initiated. The stack flow field geometries under consideration are shown in Figure 12. CFD modeling of various design configuration concepts were performed. The anode inter-mixed design utilizes dense catalyst (DIR) loading zones to achieve better $\mathrm{H}_{2}$ distribution (Figure 13) and a flatter, more uniform utilization profile in the stack. CFD modeling analysis comparing a counter flow geometry to the baseline cross flow design indicated a reduction in stack temperature gradient (see temperature distribution in Figure 14) and a more uniform current density distribution (Figure 15) are possible with the counter flow design.

\subsection{CONCLUSION}

The proof-of-concept test of the DFC/T system in the subMW power plant facility was completed achieving the milestone of being the world's first grid-connected hybrid fuel cell/gas turbine power plant. Thermal management of the system was confirmed. The control strategies were refined. System trip/emergency shutdown scenarios were tested successfully. Power plant operation, using a microturbine as the only source of fresh air supply to the system, was demonstrated. A stand-alone test of the microturbine after de-integration from the power plant facility, verified the turbine power output expected at a higher turbine inlet temperature of $1400^{\circ} \mathrm{F}$ (representative of the temperature expected in a packaged unit). 


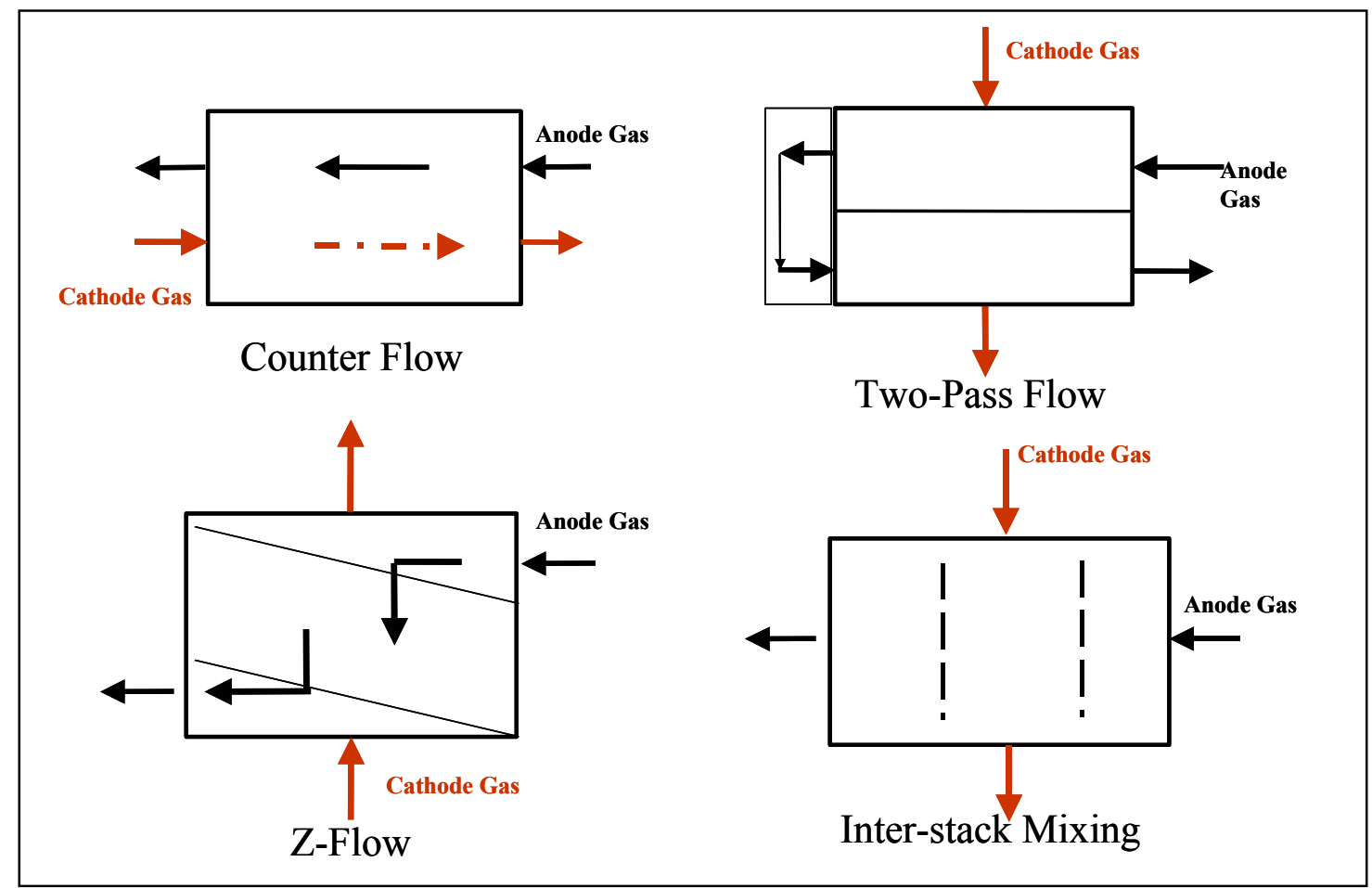

Figure 12. STACK GEOMETRIES UNDER CONSIDERATION:

Flow Field Concepts Represent Alternatives To The Baseline Cross Flow Design

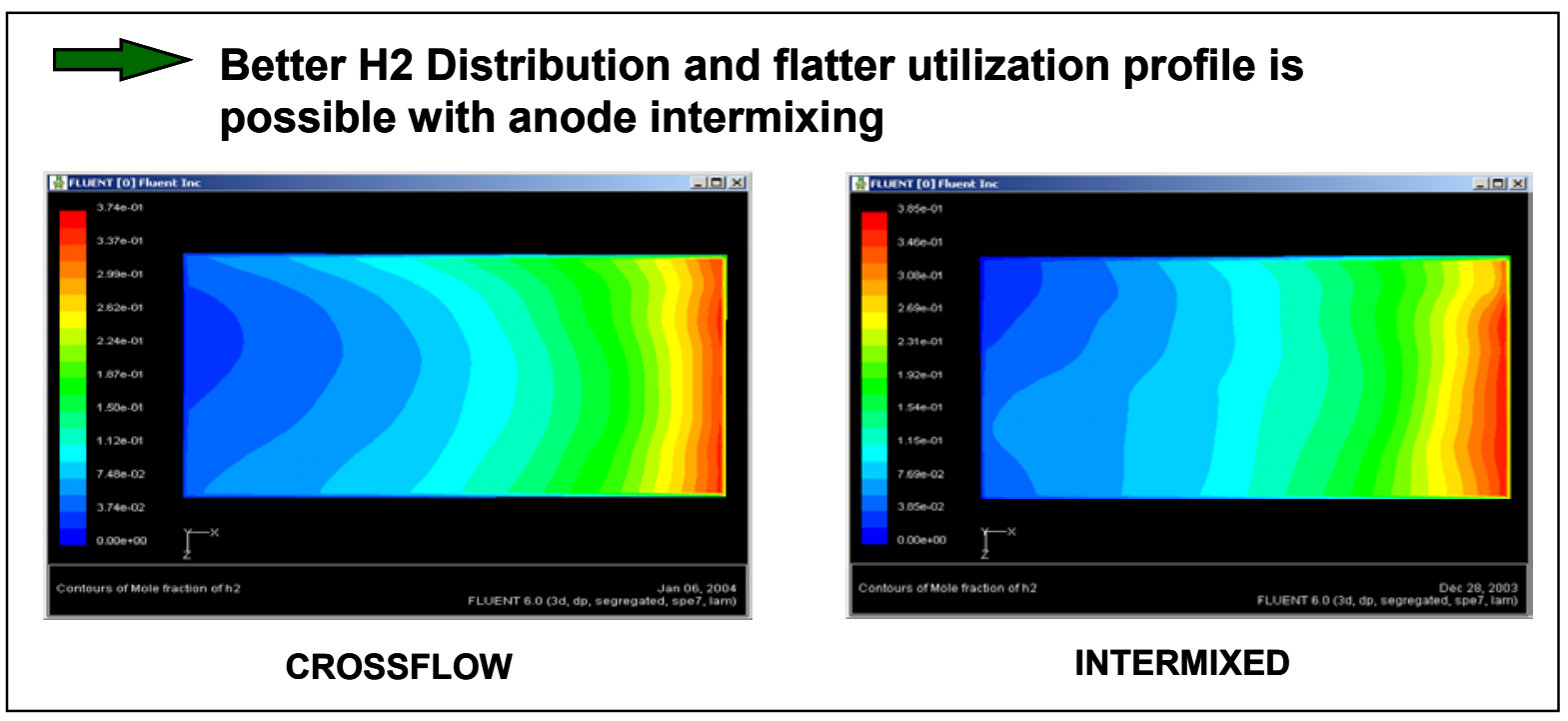

Figure 13. HYDROGEN CONCENTRATION PROFILE (MOLE FRACTION) FOR THE ANODE INTERMIXED FLOW DESIGN:

Modeled Profile Is More Uniform/Flatter Than That For The Cross Flow Design 


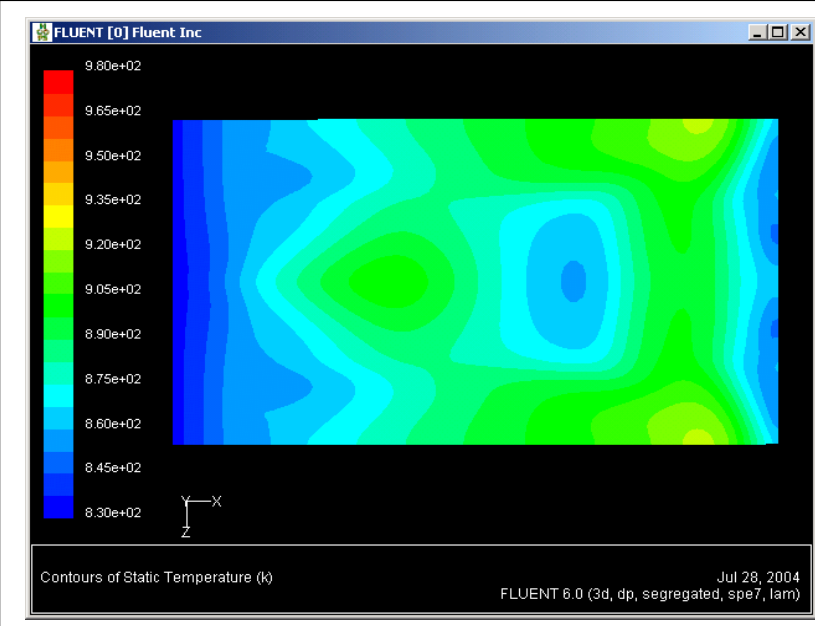

Counter Flow

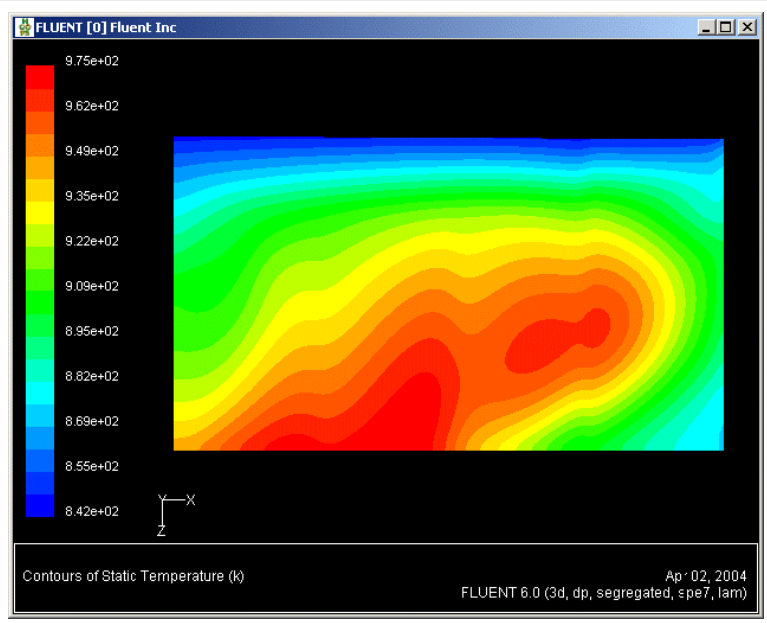

Cross Flow

Figure 14. STACK TEMPERATURE (DEGREES KELVIN) DISTRIBUTION FOR THE COUNTER FLOW DESIGN:

The Counter Flow Design Offers Reduced Temperature Gradient Compared To The Baseline Cross Flow Design

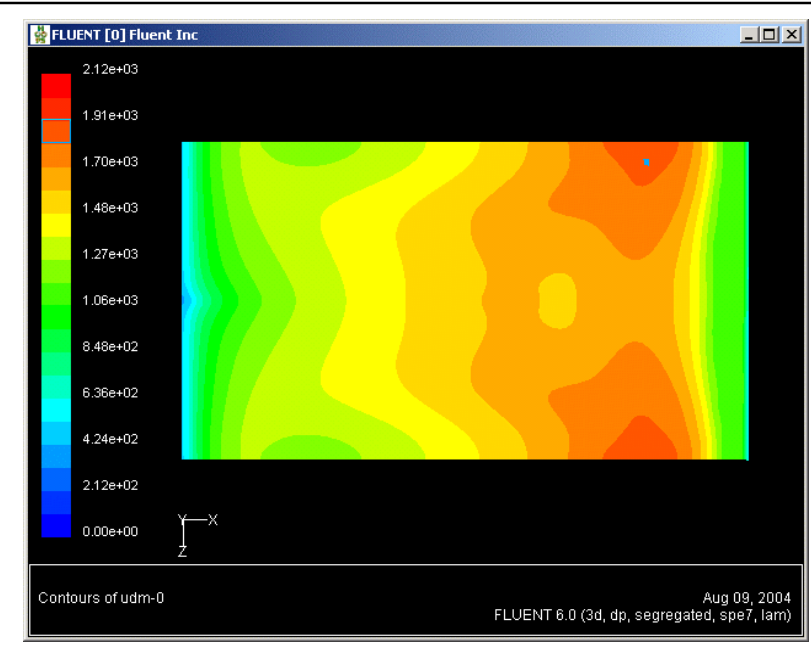

Counter Flow

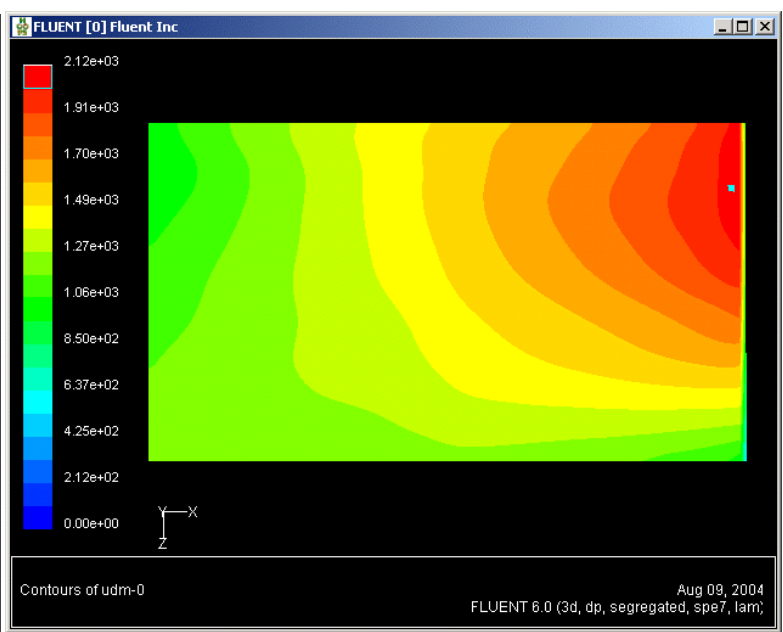

Cross Flow

Figure 15. CURRENT DENSITY $\left(\mathrm{A} / \mathrm{m}^{2}\right)$ DISTRIBUTION FOR THE COUNTER FLOW DESIGN:

The Counter Flow Design Offers A More Uniform Current Density Distribution Compared To Cross Flow Design 
The preliminary design of the subMW hybrid packaged unit (for alpha demonstration) has been completed. Design modifications to the existing DFC-300A fuel cell module for its application to the DFC300/T unit were completed. A Hazop safety review of the DFC300/T system was completed and the set of P\&IDs was refined. All major equipment and instrumentation items have been ordered. Procurement of parts and system components is in progress.

A scalable approach for the multi-MW plant design based on fuel cell clusters of the existing $1 \mathrm{MW}(\mathrm{M}-10)$ modules has been developed. Preliminary design for the $40 \mathrm{MW}$ DFC/T hybrid system using a commercially available gas turbine was completed. The system electrical efficiency (LHV) based on near-term fuel cell performance was estimated to be $62 \%$. Process flow diagrams with equipment and controls for operation and start-up have been prepared. Major equipment specifications were prepared and vendor quotes were solicited. Electrical one-line diagrams have been generated. Plant pipe sizing and insulation requirements were determined. Major equipment layouts and power plant plot plans have been generated for both power plant sizes. A preliminary cost estimate for the $40 \mathrm{MW}$ DFC/T plant has also been prepared.

A study of the 'cascaded anode' fuel cell concept was conducted for high efficiency, high power output fuel cell development needs. Tests performed using a $20 \mathrm{~kW}$ DFC stack showed that a $10 \%$ gain in fuel utilization is achievable. CFD modeling analysis of alternate stack flow geometries such as counter flow design showed potential for reduced stack temperature gradient and more uniform current density distribution, enabling higher power output/fuel utilization operations.

\subsection{REFERENCES}

H. Ghezel-Ayagh, J. Walzak, D. Patel, J. Daly, H. Maru, R. Sanderson, and W. Livingood, "Status of Fuel Cell/Turbine Systems Development", paper presented at 2004 Fuel Cell Seminar, San Antonio, TX, November 1-5, 2004. 